Kansas State University Libraries

New Prairie Press

Academic Chairpersons Conference

33rd Academic Chairpersons Conference, Proceedings

Charleston, SC

\title{
A Team-based Approach to Development
}

\author{
Katherine Frank \\ Northern Kentucky University, katherine.p.frank@cwu.edu \\ Kristi Haik \\ Northern Kentucky University, kristi.haik@nku.edu \\ Kelly Jones \\ Northern Kentucky University, jonesk36@nku.edu
}

Follow this and additional works at: https://newprairiepress.org/accp

Part of the Arts and Humanities Commons, Higher Education Administration Commons, Life Sciences Commons, and the Social and Behavioral Sciences Commons

\section{(i) $\Theta($}

This work is licensed under a Creative Commons Attribution-Noncommercial-No Derivative Works 3.0 License.

\section{Recommended Citation}

Frank, Katherine; Haik, Kristi; and Jones, Kelly (2016). "A Team-based Approach to Development," Academic Chairpersons Conference Proceedings. https://newprairiepress.org/accp/2016/Leadership/9

This Event is brought to you for free and open access by the Conferences at New Prairie Press. It has been accepted for inclusion in Academic Chairpersons Conference Proceedings by an authorized administrator of New Prairie Press. For more information, please contact cads@k-state.edu. 
Objectives:

Strategies for successful development and fundraising at the department level Various professional perspectives on the issue (dean, department chairperson, director of college development)

Examples of successful processes (short- and long-term gains)

Examples of ways to link the process to strategic planning

Time for brainstorming and discussion in small and large groups

Time for work on a development strategy and peer feedback

\section{Description:}

This workshop focuses on strategies for engaging in successful short- and long-term development and fundraising efforts at the program and department level, while remaining aligned with college and university priorities. Facilitators include a chairperson, director of college development, and dean who will discuss the development cycle and offer suggestions for working with your college development officer and dean, engaging in strategic planning, leveraging alumni and affinity groups, and working with donors. Participants will have the opportunity to brainstorm in small groups and discuss as a large group, as well as work on a development strategy that fits their unique goals and context.

The session will provide a brief overview of the fundraising cycle viewed within the context of an academic department. The facilitators will then offer strategic planning tools and techniques for developing short- and long-term development goals that are aligned with department, college, and university priorities. Finally, the facilitators will offer examples of development processes and successes that are strategic (working with advisory groups and alumni boards), organic (developing relationships), and advantageous (leveraging opportunities). Again, these processes and successes will be viewed within the context of the larger academic enterprise, and common to all is their team-based structure.

There will be time throughout the workshop for small and large group discussions, as well as for work on individual development strategies that align with specific institutional circumstances and conditions. Anticipating an audience comprised of new and experienced chairpersons from a diverse collection of institutions and regional contexts, the possibility of discussion that allows for the sharing of ideas and potential opportunities and challenges will help participants to both broaden their perspectives and understand their own circumstances more acutely.

The main objective of this workshop is to offer best practices for a team-based approach to development and fundraising during a period of limited internal and external resources in order to secure "quick wins" and ensure sustainable results. The workshop will introduce a variety of perspectives on the issue, discuss strategy, and suggest ways of moving forward towards success. Participants will leave with increased knowledge, diverse perspectives and examples, and actual progress made on a development strategy intended for implementation. 